\title{
Correction to: Game of Cruxes: co-designing a game for scientists and stakeholders for identifying joint problems
}

\author{
Nicolas Salliou ${ }^{1}$ - Enora Bruley ${ }^{2} \cdot$ Clémence Moreau $^{3} \cdot$ Tobias Luthe $^{1,4,5} \cdot$ Victor Blanco $^{1,6} \cdot$ Sandra Lavorel $^{2}$. \\ Adrienne Grêt-Regamey ${ }^{1}$
}

Published online: 28 June 2021

(c) The Author(s) 2021

\section{Correction to: Sustainability Science https://doi.org/10.1007/s11625-021-00983-2}

In the original publication of the article, one of the author "Clémence Moreau" name was not included in the author group. The correct author group is provided in this correction.

Further, the respective affiliation of the third author "Clémence Moreau" is as follows,

SENS, IRD, CIRAD, Université Paul Valery Montpellier 3, University of Montpellier, Montpellier, France.

Finally, corresponding author's first and last names were swapped. The correct name should read as "Nicolas Salliou".

The original article was updated.

The original article can be found online at https://doi.org/10.1007/ s11625-021-00983-2.

Nicolas Salliou

nsalliou@ethz.ch

1 Department of Civil, Environmental and Geomatic Engineering, Institute for Spatial and Landscape Development, Planning of Landscape and Urban Systems (PLUS), ETH Zürich, Stefano-Franscini-Platz 5, CH-8093 Zürich, Switzerland

2 Laboratoire d'Ecologie Alpine, CNRS, Université Grenoble Alpes, Université Savoie Mont Blanc, 38000 Grenoble, France

3 SENS, IRD, CIRAD, Université Paul Valery Montpellier 3, University of Montpellier, Montpellier, France

4 The Oslo School of Architecture and Design AHO, Maridalsveien 29, 0175 Oslo, Norway

5 MonViso Institute, 12030 Ostana, CN, Italy

6 Institute of Science, Technology and Policy, ETH Zürich, Universitätstrasse 41, 8006 Zürich, Switzerland
Open Access This article is licensed under a Creative Commons Attribution 4.0 International License, which permits use, sharing, adaptation, distribution and reproduction in any medium or format, as long as you give appropriate credit to the original author(s) and the source, provide a link to the Creative Commons licence, and indicate if changes were made. The images or other third party material in this article are included in the article's Creative Commons licence, unless indicated otherwise in a credit line to the material. If material is not included in the article's Creative Commons licence and your intended use is not permitted by statutory regulation or exceeds the permitted use, you will need to obtain permission directly from the copyright holder. To view a copy of this licence, visit http://creativecommons.org/licenses/by/4.0/.

Publisher's Note Springer Nature remains neutral with regard to jurisdictional claims in published maps and institutional affiliations. 